\title{
CANOPY OPENNESS AND LAI ESTIMATES IN TWO SEASONALLY DECIDUOUS FORESTS ON LIMESTONE OUTCROPS IN CENTRAL BRAZIL USING HEMISPHERICAL PHOTOGRAPHS ${ }^{1}$
}

\author{
André Rosalvo Terra Nascimento ${ }^{2}$, Jeanine Maria Felfili Fagg ${ }^{3}$ e Christopher William Fagg ${ }^{3}$
}

\begin{abstract}
Patches of seasonally dry tropical forests occur on limestone outcrops in Central Brazil surrounded by the dominant savanna vegetation. They contain valuable timber species but are threatened by farming and mining activities. The objective of this study was to describe canopy opening and light relations in two seasonally deciduous dry forests on slopes and limestone outcrops, in the Paranã valley at the northeastern region of the Goiás state, Brazil. The studied forests were in the Fazenda Sabonete in Iaciara-Go and Fazenda Forquilha in Guarani-GO. Woody plants were sampled in $25(20$ x $20 \mathrm{~m})$ plots in each forest. In the Sabonete forest 40 species, 705 ind./ha ${ }^{-1}$ with a basal area of $15.78 \mathrm{~m}^{2} / \mathrm{ha}^{-1}$ were found, while in Forquilha there were 55 species, 956 ind./ha ${ }^{-1}$ with a basal area of $24.76 \mathrm{~m}^{2} / \mathrm{ha}^{-1}$. Using hemispherical photographic techniques, 25 black and white photographs were taken at each site, during the dry season, totaling 50 photographs. These were taken at the beginning of each vegetation-sampling plot. The photographs were scanned in grey tones and saved as 'Bitmap'. The canopy opening and leaf area index (LAI) were calculated using the software Winphot. The mean canopy opening was 54.0\% ( \pm 9.36$)$ for Fazenda Sabonete and $64.6 \%( \pm 11.8)$ in Fazenda Forquilha, with both sites presenting significant differences in the opening estimates $(\mathrm{P}<0.05)$. Their floristic richness and structure also differed with the more open canopy forest, Forquilha, being richer and denser, suggesting the need for further studies on species-environment relationships in these forests.
\end{abstract}

Keywords: Canopy opening, hemispherical photographs, Cerrado.

\section{ESTIMATIVAS DE ABERTURA DO DOSSEL E ÍNDICE DE ÁREA FOLIAR EM DUAS FLORESTAS ESTACIONAIS DECIDUAIS SOBRE AFLORAMENTOS CALCÁRIOS NO BRASIL CENTRAL USANDO FOTOGRAFIAS HEMISFÉRICAS}

\begin{abstract}
RESUMO - Manchas de florestas estacionais circundadas por vegetação de cerrado ocorrem em afloramentos calcários no Brasil central. Elas contêm espécies madeireiras valiosas, mas estão ameaçadas por atividades agropecuárias e de mineração. $O$ objetivo deste estudo foi descrever a abertura de dossel e relações de luz. em duas florestas estacionais em declive sobre afloramentos calcários, no Vale do Paranã, no nordeste de Goiás. As florestas estudadas localizaram-se na Fazenda Sabonete, em Iaciara, GO, e na Fazenda Forquilha, em Guarani, GO. A vegetação lenhosa foi amostrada em 25 parcelas de $20 \times 20 \mathrm{~m}$ em cada floresta. Utilizandose a técnica de fotografias hemisféricas, 25 fotos em preto e branco foram tomadas em cada local durante a estação seca, totalizando 50 fotos. Na floresta da Fazenda Sabonete, foram encontradas 40 espécies e 705 ind./ha ${ }^{-1}$ com área basal de 15,78 $\mathrm{m}^{2} / \mathrm{ha}^{-1}$, enquanto em Forquilha se encontraram 55 espécies, 956
\end{abstract}

\footnotetext{
${ }^{1}$ Recebido em 13.06.2006 e aceito para publicação em 15.12.2006.

${ }^{2}$ Instituto de Biologia da Universidade Federal de Uberlândia, Cx. P. 593, 38400-902 Uberlândia-MG, Brasil. E-mail:<arnterra@ gmail.com>. ${ }_{3}^{3}$ Departamento de Engenharia Florestal da Universidade de Brasília, Cx. P. 02372 70919-970 Brasília-DF, Brasil. E-mail: $<$ felfili@unb.br>.
} 
ind./ha $a^{-1}$, com área basal de 24,76 $\mathrm{m}^{2} / \mathrm{ha}^{-1}$. As fotografias foram tiradas no início das parcelas, onde a vegetação foi amostrada, e digitalizadas em tons de cinza e salvas como arquivo Bitmap. A abertura do dossel e o Índice de Área Foliar (IAF) foram obtidos usando-se o programa Winphot. A abertura média de dossel foi 54,0\% (desvio-padrão = 9,36) na Fazenda Sabonete e 64,6\% (desvio-padrão = 11,8) na Fazenda Forquilha, com os locais apresentando diferença significativa nas estimativas de abertura de dossel $(P<$ 0,05). A riqueza florística e a estrutura diferiram também, com a floresta da Fazenda Forquilha, cujo dossel foi mais aberto, sendo a mais rica e densa, evidenciando a necessidade de mais estudos sobre as relações espécie-ambiente nessas florestas.

Palavras-chave: Abertura de dossel, fotografias hemisféricas e Cerrado.

\section{INTRODUCTION}

Structural variation in tropical forest canopies influences light availability and distribution. Light is the main factor that limits the growth and survival of many species, and many times its distribution affects the regeneration pattern of the stand (NICOTRA et al., 1999). In seasonal forests, the changing environmental conditions between the dry and rainy seasons, cause different reactions in the regenerating seedlings. Mortality rates of the tree seedlings were greater in the dry season, and more apparent in the deciduous forest in comparison with a semi deciduous forest in Costa Rica (GERHARDT, 1996).

Tropical plants grouped into categories such as shade tolerant or gap colonizers (BUDOWSKI, 1970; MARTÍNEZ-RAMOS, 1994) show distinct responses to the varied micro-climatic conditions. With respect to changing micro environmental conditions in gaps, some studies have demonstrated differences in the ecophysiological response of plants, especially in photosynthetic rates (CHAZDON e FLETCHER, 1984; LIBERMAN et al., 1989, AVALOS e MULKEY, 1999).

Two optical methods are commonly used for measurement of the indirect canopy parameters (openness and leaf area index): Licor 2000 sensor (LAI 2000) and optical hemispherical photographs (WELLES e NORMAN, 1991). Canopy opening and leaf area index (LAI) are two biophysical variables in the canopy structure (WELLES e NORMAN, 1991, ter STEEGE, 1997), and are related with the structural and vertical variation that occurs in distinct vegetation types in tropical regions (NELSON, 1997). The heterogeneity of light distribution increases with differences in light availability during the day and between seasons, tree type, branch fall, and shade produced by trees and lianas. Considering the long life cycles of the trees and lianas in dry forests, it is evident that there is acclimatization of the existing leaves to light periods of short wavelengths and periods of dramatic changes in the environmental conditions that occur in the upper canopy structures (AVALOS e MULKEY, 1999).

Hemispherical photographs give estimates of canopy openness (and gap fractions), leaf area index (LAI) and leaf angle. In this method, hemispherical photographs (or fish-eye) are taken using lens with a $180^{\circ}$ capture, which produces a circular projection similar to the sky hemisphere (ter STEEGE, 1997).

Patches of seasonally dry tropical forests occur on limestone outcrops in Central Brazil surrounded by the dominant savanna vegetation. They contain valuable timber species that are threatened by farming and mining activities (FELFILI, 2003), requiring strategies for conservation and sustainable management. These patches are largely unknown to science and were not included in the analyses of seasonal tropical forests of South America (PENNINGTON et al., 2000), although their floristics (SILVA e SCARIOT, 2003; 2004a,b; NASCIMENTO et al., 2004) indicates links with the continuous seasonal forests that occur in Northeastern Brasil (FELFILI, 2003) and in the Southwest of South America. The classification of these forests as deciduous is based on visual estimates indicating that their canopy presents more than $50 \%$ of opening in the dry season (RIBEIRO e WALTER, 1998). In the IBGE (Brazilian Institute for Geography and Statistics) vegetation map (www.ibge.gov.br) at 1:5 million scale, the areas where these patches occur are classified as transitional zones between cerrado and seasonal forests and are officially unprotected, which leads to uncontrolled logging and mining.

Measures of canopy opening have not been reported for natural fragments of deciduous forests on limestone

R. Árvore, Viçosa-MG, v.31, n.1, p.167-176, 2007 
outcrops in Central Brasil (FELFILI, 2003). The hypothesis proposed by this work was that the canopy opening of these forests is on average above $50 \%$ during the dry season.

The objective of this study was to characterize the canopy opening and the main light conditions in two seasonally deciduous forests, and to compare the estimated values of canopy opening and LAI between the two sites.

\section{MATERIALAND METHODS}

\subsection{Study sites}

The present work was conducted in two patches of seasonally deciduous forest at the Fazenda Sabonete in Iaciara-GO $\left(14^{\circ} 03^{\prime} 53\right.$ ' S; $\left.46^{\circ} 29^{\prime} 15^{\prime \prime} \mathrm{W}\right)$ and at the Fazenda Forquilha in Guarani-GO (13 ${ }^{\circ} 48^{\prime} 19^{\prime}$ ' S; $46^{\circ}$ 31 ' $\left.48^{\prime \prime} \mathrm{W}\right)$. These sites are located in the Paranã valley, Northeastern Goiás, which was included in the Cerrado Biosphere Reserve Phase 2 and it is also considered a priority ecological corridor for conservation of cerrado and deciduous forests by IBAMA (Brazilian Institute for the Environment).

The vegetation of this region is composed by a mosaic of cerrado sensu lato, deciduous and semideciduous forests (IBGE, 1990). Seasonally deciduous forests tend to occur in disjunct patches in the neotropics (PENNINGTON et al., 2000) and also in Paranã valley, consisting of trees that are deciduous in the dry season (FELFILI, 2003). The two studied forests are primary forests (sensu Gentry, 1995) with low density of pioneers and a few large trees. There was no evidence of major logging.

The altitude varies between $200-500 \mathrm{~m}$, with gently undulating slope (3-8\%), but with steeper parts and undulating slopes (13-20\%) in the hills (FINATEC, 2001). The two patches of seasonally deciduous sloping forests are situated on rocky calcareous outcrops.

\subsection{Vegetation sampling}

The woody vegetation was sampled in $25(20 \mathrm{x}$ $20 \mathrm{~m}$ ) plots comprising a sample of 1 ha in each forest patch. The plots were randomly located along four transects also randomly placed within the forest, going from one edge to the other (FELFILI, 1995). Girth at breast height $(\mathrm{gbh} \geq 15.7 \mathrm{~cm}=$ diameter at breast height $\mathrm{dbh} \geq 5 \mathrm{~cm}$ ) and total height were measured for all woody individuals that were tagged with aluminium labels. The species were identified and botanical vouchers were deposited in the IBGE herbarium.

Density and basal area were calculated (KENT e COKER, 1992) using the Software INFLO I developed at the University of Brasília. Diameter distribution was also calculated using Spiegel's formula quoted by Felfili e Rezende (2003) to find the ideal class intervals.

The calcareous rocky soil cover was estimated for each $400-\mathrm{m}^{2}$ plot. Taking into account the slope of the land and the presence of rocky outcrops the cover estimates were broken into four categories: 0 to $25 \%$ cover, 26 to $50 \%, 51$ to $75 \%$ and 76 to $100 \%$.

\subsection{Canopy opening and LAI estimates}

Twenty-five hemispherical photographs were taken in each forest, one per $20 \times 20 \mathrm{~m}$ random-plot, in the middle of the dry season, to estimate the canopy opening and LAI. A total of 50 photographs were taken altogether using a Nikkor $8 \mathrm{~mm}$ fish-eye lens. The camera was mounted on a leveled tripod at $1.3 \mathrm{~m}$ above the soil, with the fish eye focus setting into infinity (MITCHELL e WHITMORE, 1993). This height was established for being the height that the gbh (girth at the breast height) of the trees was measured in the forest inventory.

The black and white photographs were taken on an AGFA ASA 400 film in the morning, until about 10 $\mathrm{h}$ and in the afternoon from 15:00 $\mathrm{h}$ to avoid over-exposure from the midday sun. The developed photographs were scanned as images in grey tones, using the table scanner Genius Color page - HR7X and saved as Bitmap - bmp extensions, which were then imported into Winphot 5.0 Software. This software accepted PCX type files (Standard of Zsoft) with 1 to 8 bits per pixel (bpp) and BMP files (Windows native image format) of 1 to 8 bpp. Later, a new palette of grey scales was created: $1 \mathrm{bpp}=2$ colours (black and white) and $8 \mathrm{bpp}=(256$ grey tones). The Winphot assumes that the first palette is low light tones, and gives its value as 0 . The grey tones are converted into black and white images with 256 grey scales ( 8 bits).

The total foliar area per unit of ground area, leaf area index (LAI), was obtained by an indirect method based upon the determination of gap fractions in the foliage considering that light has a chance to be intercepted by leaves as it passes through the vegetation. Five viewing angles are used with Winphot 5.0: 7, 23,

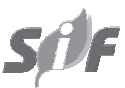

R. Árvore, Viçosa-MG, v.31, n.1, p.167-176, 2007 
$38,53,68$. The gap fraction (openness, T) around each viewing angle, in bands of 15 degrees, is calculated with similar methods as in total openness (WELLES e NORMAN, 1991) for the hemisphere and total LAI is then calculated by the equation $\mathrm{LAI}=\operatorname{Sum}[-\ln \mathrm{T}(\mathrm{a})$ * W(z)/S(z) ] (WELLES e NORMAN, 1991), where $\mathrm{z}$ takes the five values mentioned above, $\mathrm{Wz}$ are weights to account for area correction and $\mathrm{S}(\mathrm{z})$ are the reciprocal path length corrections (1/cos[Theta(z)]) (ter STEEGE, 1997). The artificial images of the canopy are created with LAI values from 1 to 10 , assuming a spherical angle in the leaf distribution. Each point in the image is randomised, assuming the pixel white or black depending on the angle of vision and the theoretical mean opening $(\mathrm{Tz})$ of this angle $\left(\mathrm{Tz}=\mathrm{e}^{\wedge}[(-\mathrm{LAI} / 2) / \cos (\mathrm{z})]\right)$, where $e^{\wedge}=$ exponential (ter STEEGE, 1997).

\subsection{Data analysis}

Estimates of canopy opening (\%), Leaf area index (LAI) $\left(\mathrm{m}^{2} / \mathrm{m}^{2}\right)$ and gap fraction were calculated and the mean values estimated for the 25 photographs at each forest.

The data was tested for normality using the Kolmogorov-Smirnov test and the variances tested in relation to homogeneity using the Bartlett test (ZAR, 1996). The mean values for canopy opening, LAI and total radiation at 1.3 meters, were compared using the Student's t-test. These two tests were performed in SAS software version 8 (SAS, 1999-2001), then the canopy opening and LAI values were plotted using Box and Wisker plots.

Pearson's correlation coefficient ( $\mathrm{r}$ ) was calculated and the LAI and canopy opening variables adjusted in a linear regression model. The selected model (ZAR, 1996) was the one with the greatest coefficient of determination $\left(\mathrm{r}^{2}\right)$, at the highest probability value $(\mathrm{P}<0.0001)$.

\section{RESULTS}

\subsection{Floristic structure and composition}

A total of 40 species with 705 ind./ha ${ }^{-1}$ and a basal area of $15.78 \mathrm{~m}^{2} / \mathrm{ha}^{-1}$ were found in the Sabonete forest, while in Forquilha, there were 55 species with 956 ind./ $\mathrm{ha}^{-1}$ and a basal area of $24.76 \mathrm{~m}^{2} / \mathrm{ha}^{-1}$ (Table 1 ). The two forests showed a high similarity of tree species by the Sorensen's index, which is based on presenceabsence of species, of $62 \%$, and the Czekanowski's index, based on density of species, of $62.84 \%$, with 30 common species between the site species and the list available with the authors. Both indices were above $50 \%$, limit accepted by many authors (KENT e COKER, 1992, FELFILI e REZENDE, 2003) to consider the similarity between two sites as high. The Forquilha forest was richer, with a greater proportion of exclusive species (42.1\% of total) compared with Sabonete forest (22.5\%).

The diameter distribution of individual species with $\mathrm{dbh} \geq 5 \mathrm{~cm}$ (Figure 1) followed the reversed-J model for both sites, with a greater number of individuals in smaller diameter classes. In both sites, $90 \%$ of the individuals were under $30 \mathrm{~cm} \mathrm{dbh}$, but some reached more than $100 \mathrm{~cm}$. The distribution did not differ between Sabonete and Forquilha forests by the KolmogorovSmirnov test with $\mathrm{d}=0.389 ; \mathrm{p}<0.05$.

\subsection{Canopy openings and LAI}

The Forquilha forest in Guarani-GO presented the highest values of canopy opening (Table 2 ) with mean $( \pm$ SD) of $64.6 \%( \pm 11.8)$ and differed significantly from Sabonete forest in Iaciara-GO with 54,0\% ( \pm 9.36$)$ by the $\mathrm{t}$-test $(\mathrm{t}=-3.751 ; \mathrm{P}<0.0005)$.

Leaf area index $(\mathrm{LAI})\left(\mathrm{m}^{2} / \mathrm{m}^{2}\right)$ was higher in Sabonete forest (mean $=0.64 \pm 0.18$ ) than in Forquilha forest (mean $=0.46 \pm 0.22$ ), indicating a greater canopy cover. There was a greater symmetry for Forquilha forest (Figure 2 ) in percentiles in relation to the mean values of canopy opening and LAI. These agree with the low LAI standard deviation values, and the estimated means were close to the medians, which was expected, considering that the values varied from 0.13 to $0.94 \mathrm{~m}^{2} / \mathrm{m}^{2}$ in the sampled points.

Table 1 - Phytossociological parameters of two sloping seasonally deciduous forests in Iaciara-Fazenda Sabonete and Guarani-Fazenda Forquilha in Northeastern Goiás, Brazil

Quadro 1 - Parâmetros fitossociológicos de duas florestas estacionais deciduais de encosta em Iaciara-Fazenda Sabonete e Guarani-Fazenda Forquilha no nordeste do Estado de Goiás, Brasil

\begin{tabular}{lcc}
\hline Parameters & $\begin{array}{c}\text { Fazenda Sabonete, } \\
\text { Iaciara- GO }\end{array}$ & $\begin{array}{c}\text { Fazenda Forquilha, } \\
\text { Guarani- GO }\end{array}$ \\
\hline $\mathrm{N}^{\mathrm{o}}$ species & 40 & 55 \\
$\mathrm{~N}^{\mathrm{o}}$ Families & 22 & 23 \\
Density $\left(\right.$ ind. $\left./ \mathrm{ha}^{-1}\right)$ & $705( \pm 90.5)$ & $956( \pm 85.2)^{*}$ \\
Basal area $\left(\mathrm{m}^{2} / \mathrm{ha}^{-1}\right)$ & $15.78( \pm 3.5)$ & $24.76( \pm 5.25)$ \\
\hline
\end{tabular}

* Confidence intervals at $95 \%$ probability level between brackets. 


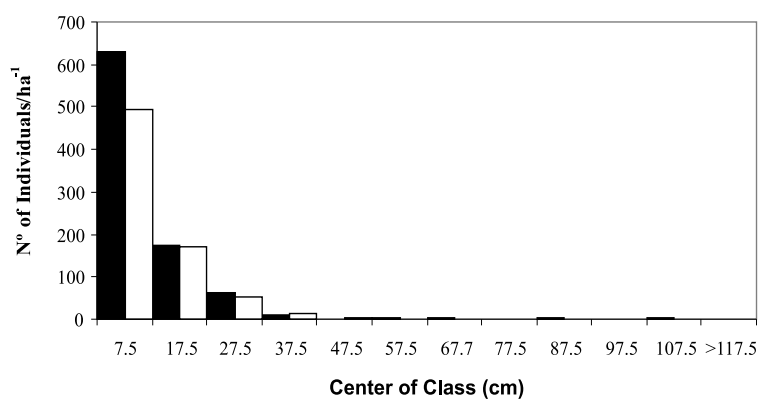

Figure 1 - Diameter distributions for two seasonally deciduous forests in Northeastern Goiás, Brazil (Fazenda Sabonete in Iaciara, GO - white and Fazenda Forquilha in Guarani, GO - black).

Figura 1 - Distribuição diamétrica de duas florestas estacionais deciduais na região nordeste do estado de Goiás, Brasil (Fazenda Sabonete em Iaciara, GO - branco e Fazenda Forquilha em Guarani, GO - preto).

Table 2 - Estimates of canopy opening and LAI at $1.3 \mathrm{~m}$ above soil level in two sloping seasonally deciduous forests in Iaciara-Fazenda Sabonete and GuaraniFazenda Forquilha in Northeastern Goiás, Brazil

Quadro 2 - Estimativas de abertura do dossel e IAF tomadas a 1,3 macima do solo em duas florestas estacionais deciduais de encosta, em Iaciara-Fazenda Sabonete e Guarani-Fazenda Forquilha, no nordeste do Estado de Goiás, Brasil

\begin{tabular}{|c|c|c|}
\hline $\begin{array}{l}\text { Biophysical } \\
\text { parameters }\end{array}$ & $\begin{array}{c}\text { Fazenda Sabonete, } \\
\text { Iaciara- GO }\end{array}$ & $\begin{array}{c}\text { Fazenda Forquilha, } \\
\text { Guarani-GO }\end{array}$ \\
\hline $\begin{array}{l}\text { Canopy } \\
\text { opening (\%) }\end{array}$ & $54.0 a \quad( \pm 9.36)$ & $64.6 b( \pm 11.8)^{*}$ \\
\hline $\begin{array}{l}\text { Range of } \\
\text { variation }(\%)\end{array}$ & $42.2-79.5$ & $42.4-84.9$ \\
\hline Median & 49.3 & 63.1 \\
\hline $\operatorname{LAI}\left(\mathrm{m}^{2} / \mathrm{m}^{2}\right)$ & $0.64 a( \pm 0.18)$ & $0.46 b( \pm 0.22)^{*}$ \\
\hline $\begin{array}{l}\text { Range of variation } \\
\left(\mathrm{m}^{2} / \mathrm{m}^{2}\right)\end{array}$ & $0.23-0.94$ & $0.13-0.9$ \\
\hline Median & 0.70 & 0.45 \\
\hline
\end{tabular}

*Averages followed by the same letter did not differ by the Student's t-test $(* \mathrm{P}<0.05)$.

Significant negative correlation was found between LAI and canopy opening $(\mathrm{r}=-0.97, \mathrm{P}<0.0001)$ for both forests (Figure 3). Most points were adjusted by the equation, with greater variation for points from more closed canopies, and consequently a greater leaf area index (LAI) (Figure 3).

The estimated rocky cover in the plots of both fragments was similar, with average values of $66.8 \%$ in Fazenda Forquilha and 61.0\% in Fazenda Sabonete.
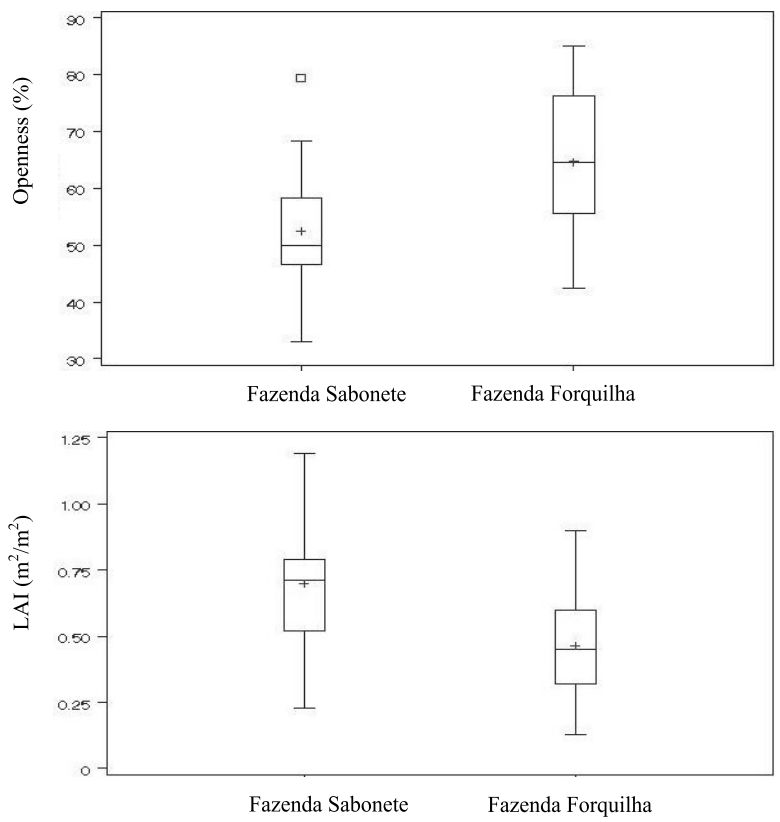

Figure 2 - Box and Whisker plots for (a) canopy opening $(\%)$, and (b) leaf area index (LAI) $\left(\mathrm{m}^{2} / \mathrm{m}^{2}\right)$ at 1.3 $\mathrm{m}$ above soil level for two forests in Northeastern Goiás, Brazil, using hemispherical photographs $(\mathrm{n}=25$ photos/forest). Note the diferences between forests, with Sabonete Forest (left) showing the smaller canopy opening and larger LAI than Forquilha forest (right).

Figura 2-Diagrama de Box and Whisker plots para (a) abertura do dossel $(\%)$ e (b) índice de área foliar $\left(\mathrm{m}^{2} / \mathrm{m}^{2}\right)$ a 1,3 $\mathrm{m}$ do solo em duas florestas na região nordeste do Estado de Goiás, Brasil, usando-se fotografias hemisféricas ( $n=25$ fotos/floresta). Notar as diferenças entre as florestas, com a floresta da Fazenda Sabonete (esquerda) mostrando uma menor abertura de dossel e um maior IAF do que Forquilha (direta).

\section{DISCUSSION}

Sabonete and Forquilha forests, with canopy openness above $50 \%$ and LAI under $1 \mathrm{~m}^{2} / \mathrm{m}^{2}$ at most points, were within the range found in most seasonal forests for these variables (Table 2) and agreed with the ranges quoted by Gerhardt (1996) and Baldochi et al. (1984) that found canopy openness above $50 \%$ and LAI under $2 \mathrm{~m}^{2} / \mathrm{m}^{2}$ in the dry season. Even if belonging to similar type of forest, they presented significant differences for the mean values of canopy opening $(\mathrm{P}<0.05)$ and leaf area index $(\mathrm{P}<0.05)$, showing the largest structural variation found in these forests. The forest structure has a mosaic of areas, some more

R. Árvore, Viçosa-MG, v.31, n.1, p.167-176, 2007 
open than others, and areas similar to large gaps (Figure 4), where high levels of radiation reach the forest floor indicating a discontinuous canopy. Plants grow on and around calcareous rock outcrops, which sometimes are large blocks with no plants on them, therefore ground conditions contribute to canopy openness. Further studies on plant-environment relationships are needed to elucidate these forests' floristic and structural patterns.

LAI estimates were also similar to those recorded in other deciduous forests, for instance LAI values (from 0.33 to $0.96 \mathrm{~m}^{2} / \mathrm{m}^{2}$ ) recorded by Gendron et al. (2001) in six deciduous forest sites in Vancouver, Canada (using a Licor 2000 sensor), in the dry season, and $0.56\left(\mathrm{~m}^{2} / \mathrm{m}^{2}\right)$ by Brina e Lemos-Filho (1996) for a seasonally deciduous aroeira forest on limestone outcrops, in the dry season, also using hemispherical photography. These values were lower than those found for semideciduous forests in Minas Gerais (0.78 and 1.3) by Paula e Lemos Filho (2001). During the dry season, the LAI values were very low $\left(<1 \mathrm{~m}^{2} / \mathrm{m}^{2}\right)$ in these two seasonally deciduous forests, with a sparse cover formed by lianas and some legume species (mostly Acacia and Bauhinia species).

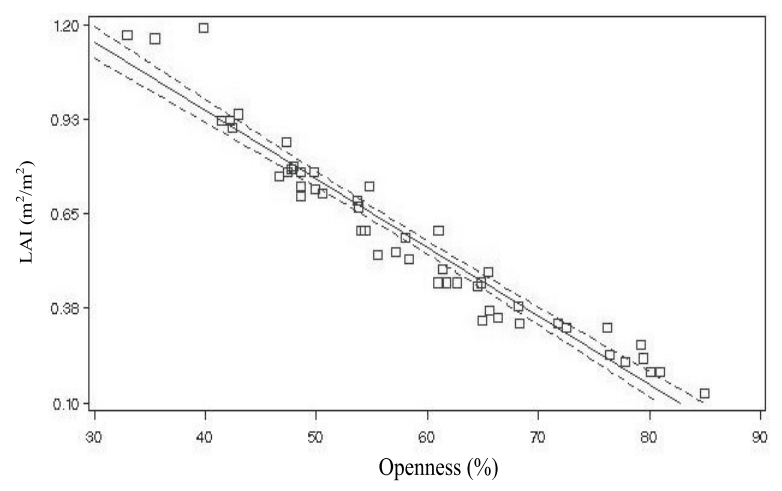

Figure 3 - Relation between $\mathrm{LAI}\left(\mathrm{m}^{2} / \mathrm{m}^{2}\right)$ and canopy openness $(\%)(r=-0.97, P<0.0001)$ for the two seasonally deciduous dry forests, Northeastern Goiás, Brazil, (Openness = 1.6110-0.0189. LAI ; F = 1169.87). The dotted lines represent the probability level at $95 \%$.

Figura 3 - Relação entre IAF $\left(\mathrm{m}^{2} / \mathrm{m}^{2}\right)$ e abertura do dossel (\%) $(r=-0,97 ; P<0,0001)$ para duas florestas estacionais deciduais, região nordeste do estado de Goiás, Brasil (Abertura = 1,6110-0,0189. IAF; $F=1169,87$ ). A linha pontilhada representa os limites de probabilidade de $95 \%$.

R. Árvore, Viçosa-MG, v.31, n.1, p.167-176, 2007
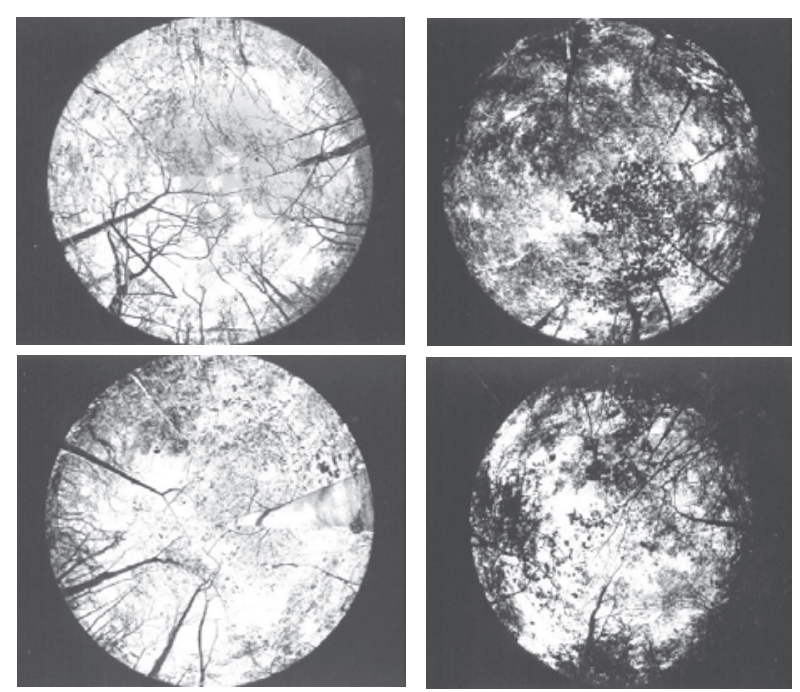

Figure 4 - Hemispherical photographs taken at 1.3 meters above soil level during the dry season in two sites of seasonally deciduous forest, in the northeast Goiás state, Brazil. Note the great variation in cover represented by stems and branches (in lesser quantity) of leafless species. The two principal environments represented are: a closed canopy (photos on the right) with cover $>50 \%$ and an open canopy (photos on the left), similar to a large gap, with a canopy opening above $70 \%$ (LAI $<0.4 \mathrm{~m}^{2} / \mathrm{m}^{2}$ ).

Figura 4-Fotografias hemisféricas tomadas a 1,3 metros do solo durante a estação seca em duas florestas estacionais deciduais na região nordeste do Estado de Goiás, Brasil. Notar a grande variação na cobertura representada por troncos e galhos (em menor quantidade) das espécies sem folhas. Os dois principais ambientes de luz estão aqui representados: o dossel fechado (fotos da direita) com cobertura $>50 \%$ e o dossel aberto (fotos da esquerda), similar a grandes clareiras, com abertura do dossel acima de $70 \%\left(\right.$ IAF $\left.<0,4 \mathrm{~m}^{2} / \mathrm{m}^{2}\right)$.

For a gallery forest in Central Brazil, Felfili e Abreu (1999) and Felfili et al. (2001) described a drastic reduction in light intensity under the canopy and changes in light quality mainly with a reduction in the red/far red ratios (V/VE). In the gallery forest studied by Felfili e Abreu (1999), the density of the photon flux (DFF) measured was low under the canopy, varying from $0.27 \%$ to $2.09 \%$ with means around $1 \%$, and also in gaps varying from $1.67 \%$ to $32.4 \%$ with means between $5 \%$ and $32 \%$. According to the authors, greater part of the solar radiation reaching the gallery forest floor is derived from sun flecks, making available light a limiting factor 
for seedling development both in shaded environments and other tropical forests (KABAKOFF e CHAZDON 1996). In these two seasonal forests a larger quantity of solar radiation may reach the forest floor but the pattern is also diffuse.

LAI was negatively correlated with canopy opening in the two forests and also in six sites in a tropical humid forest studied by Kabakoff e Chazdon (1996). In dense tropical forest, the canopy opening is smaller $(<10 \%)$ (Table 3), while in the seasonal forests canopy opening varies from 33 to over $60 \%$.

Light conditions together with water availability and soil fertility are important determinants of vegetation in central Brazil, selecting species with different features for the different environments of the vegetational mosaic within the Cerrado Biome. Gouveia e Felfili (1998) showed distinct patterns of leaf phenology with growing decidousness from seasonal to evergreen vegation, probably due to diferences in water disponibility througout the year and root structure of the cerrado plants opposed to the gallery forests. Alvarenga et al. (2003) demonstrated that the seedling root system of a pioneer forest species showed higher dry biomass under full sunlight with a tendency to increase chlorophyll concentration and to decrease photosynthetic rate with the increase of the shading level.

The use of hemispherical photographs to describe the canopy opening (Table 3) and to identify the light environments proved accurate, producing estimates with a standard deviation of $11.8 \%$ and $9.36 \%$ for the two sites respectively $(\mathrm{N}=25$ photographs per forest).

Table 3 - Percentage of canopy opening in two sloping seasonally deciduous forests in Iaciara-Fazenda Sabonete and GuaraniFazenda Forquilha in Northeastern Goiás, Brazil, and in different vegetation types, using hemispherical photographs Quadro 3 - Porcentagem de abertura do dossel nas duas florestas estacionais deciduais de encosta em Iaciara-Fazenda Sabonete e Guarani-Fazenda Forquilha no nordeste do estado de Goiás, Brasil, e em diferentes tipos de vegetação, usando-se fotografias hemisféricas

\begin{tabular}{|c|c|c|c|}
\hline Openness $(\%)$ & Forest type & Season & Study \\
\hline 64.6 & Deciduous Dry Forest & dry & Fazenda Forquilha, this study \\
\hline 52.4 & Deciduous Dry Forest & dry & Fazenda Sabonete, this study \\
\hline 33.7 & Deciduous Dry Forest & dry & Gerhardt (1996) \\
\hline 33.6 & Aroeira Forest & dry & Brina \& Lemos-filho (1996) \\
\hline 13.3 & Semi-deciduous Forest & dry & Holdridge et al. (1971) \\
\hline 32.9 & Savanna formation & dry & Holdridge et al. (1971) \\
\hline $20.0(10-30)$ & Temperate Forest & -- & Silbernagel e Moeur (2001) \\
\hline 13.3 & Semi-deciduous Forest & dry & Holdridge et al. (1971) \\
\hline 10.7 & Dipterocarp Forest & wet & Zipperlin e Press (1996) \\
\hline 10.0 & High Cerrado Forest & - & Wenzel e Hampel (1998) \\
\hline 6.0 & Tropical Forest (dense) & wet & Nicotra et al. (1999) \\
\hline 5.1 & Tropical Forest (dense) & wet & Trichon et al. (1998) \\
\hline 4.9 & Tropical Forest (mixed) & wet & Molofsky e Fisher (1993) \\
\hline 3.5 & Tropical Forest (dense) & wet & Grove et al. (2000) \\
\hline
\end{tabular}

— without information.

\section{CONCLUSION}

The estimates of canopy opening above $50 \%$ and LAI below $<1 \mathrm{~m}^{2} / \mathrm{m}^{2}$ for most of the points in the two forests, were within the range of those found in other seasonally deciduous forests during the dry season. Therefore, these two forests occurring on limestone outcrops in the Paranã Valley can be classified amongst the seasonally deciduous forests of South America.

The great variety of canopy openings and the differences in cover and LAI between the two sites in the deciduous forest highlight the spatial heterogeneity in the vegetation mosaic at the community level.

\section{ACKNOWLEDGMENTS}

The authors would like to thank MMA-PROBIO, DFID-UK, CAPES and CNPq for the financial support. To Dr. Aldicir Scariot, coordinator of the Project "Strategies for conservation and management of biodiversity in fragments of Semideciduous Forests". To the many people who helped in the undertaking this project.

R. Árvore, Viçosa-MG, v.31, n.1, p.167-176, 2007 


\section{REFERENCES}

AVALOS, G.; MULKEY, S. S. Photosynthetic acclimation of the liana Stigmaphyllon lindenianun to light changes in Tropical Dry forest canopy.

Oecologia, v.120, p.475-484, 1999.

ALVARENGA, A.A. et al. Efeito de diferentes níveis de radiação sobre o crescimento inicial e fotossíntese de plantas de Croton urucurana Baill. na região sudeste do Brasil. Revista Árvore, v.27, n.1, p.53-57, 2003.

BALDOCHI, D.D. et al. Seazonal variations in the radiation regime within an Oak-hickory forest. Agricultural and Forest Meteorology, v.33, p.177-191, 1984.

BRINA, A.E.; LEMOS FILHO, J.P. Estudo da estrutura e dinâmica do dossel de uma mata de aroeiras (Myracrodrum urundeuva) através de fotografias hemisféricas. In: FOREST' 96 SIMPÓSIO INTERNACIONAL SOBRE ECOSSISTEMAS FLORESTAIS, 4., 1996, Belo Horizonte. Anais... Belo Horizonte: Biosfera, 1996. p.334-336.

BUDOWSKI, G. The distinction between old secondary and climax species in Tropical Central American lowland forest. Tropical Ecology, v.11, p.44-48, 1970.

CHAZDON, R.L.; FLETCHER, N. Photosynthetic light environment in Lowland tropical forest in Costa Rica. Journal of Ecology, v.72, p.553-564, 1984.

FELFILI, J.M. Diversity, structure and dynamics of a gallery forest in central Brazil. Vegetatio, v.117, p.1-15, 1995.

FELFILI, J.M.; ABREU, H. M. Regeneração natural de Roupala montana Aubl., Piptocapha macropoda Back. e Persea fusca Mez. em quatro condições ambientais em mata de galeria na mata de galeria do Gama-D.F. Cerne, v.6, n.2, p.125-132, 1999.

FELFILI, J.M. et al. Desenvolvimento inicial de espécies de Mata de Galeria. In: RIBEIRO, J.F.; FONSECA, C.E.L.; SOUSA-SILVA, J.C. (Ed.). Cerrado: caracterização e recuperação de Matas de galeria. Planaltina: Embrapa- CPAC, 2001. p.779-811.

R. Árvore, Viçosa-MG, v.31, n.1, p.167-176, 2007
FELFILI, J.M. Fragmentos de florestas estacionais do Brasil Central: diagnóstico e proposta de corredores ecológicos. In: COSTA, R.B. (Org.) Fragmentação florestal e alternativas de desenvolvimento rural na Região Centro-Oeste. Campo Grande: UCDB, 2003. p.139-160.

FELFILI, J.M.; REZENDE, R.P. Conceitos e métodos em fitossociologia. Brasília: Universidade de Brasília, Departamento de Engenharia Florestal, 2003. 68p. (Comunicações Técnicas Florestais, v.5, n.1).

FINATEC. Inventário Hidrelétrico da Bacia do Rio Paranã. Mapas de vegetação, solos e geologia. Brasília: 2001.

GENDRON, F.; MESSIER, C.; COMEAU, P.G. Temporal variations in the under-story photosynthetic photon flux density of deciduous stand: the effects of canopy development, solar elevation, and sky conditions. Agricultural and Forest Meteorology, v.106, p.23-40, 2001.

GENTRY, A.H. Diversity and floristic composition of Neotropical dry forests. In: BULLOCK, S.H.; MOONEY, H.A.; MEDINA, E. (Ed.) Seasonally dry tropical forests. Cambridge: Cambridge University Press, 1995. p.146-194.

GERHARDT, K. Effects of root competition and canopy openness on survival and growth of tree seedlings in a tropical seasonal dry forest. Forest Ecology and Management, v.82, p.33-48, 1996.

GOUVEIA, G. P.; FELFILI, J. M. Fenologia de comunidades de matas de galeria e de cerrado no Distrito Federal. Revista Árvore, v.22, n.4, p.443-450, 1998.

GROVE, S. J.; TURTON, S. M.; SIEGENTHALER, D. T. Mosaics of canopy openness induced by tropical cyclones in lowland rain forests with contrasting management histories in northeastern Australia. Journal of Tropical Ecology, v.16, p.883-891, 2000. 
HOLDRIDGE, L.R. et al. Forest environments in tropical life zones- a pilot study. Oxford: Pergamon Press, 1971.747p.

INSTITUTO BRASILEIRO DE GEOGRAFIA E ESTATÍSTICA - IBGE. Mapa da vegetação Brasileira. Rio de Janeiro: 1990.

KABAKOFF, R.P.; CHAZDON, R. L. Effects of canopy dominance on under-story light availability in low-elevation secondary stands in Costa Rica. Journal of Tropical Ecology, v.12, p.779-788, 1996.

KENT, M.; COKER, P. Vegetation description and analysis. London: Belhaven Press, 1992. 384p.

LIEBERMAN, M.; LIEBERMAN, D.; PERALTA, R. Forests are not just Swiss cheese: canopy stereogeometry of non gaps in tropical forests. Ecology, v.70, p.550-552, 1989.

MARTÍNEZ-RAMOS, M. Regeneración natural y diversidad de especies arboreas en selvas húmedas. Boletin Sociedad Botanica do Mexico, v.54, p.179-224, 1994.

MITCHELL, P.L.; WHITMORE, T.C. Use of hemispherical photographs in forest ecology. Oxford: Oxford Forestry Institute, 1993. 39p. (Oxford Occasional Papers, n. 44).

MOLOFSKI, J.; FISHER, B. L. Habitat and predation effects on seedlings survival and growth in shade-tolerant tropical species. Ecology, v.74, p.261-265, 1993.

NASCIMENTO, A. R. T.; FELFILI, J. M.; MEIRELLES, E. M. Florística e estrutura da comunidade arbórea de um remanescente de Floresta Estacional Decidual de encosta, Monte Alegre, GO, Brasil. Acta Botânica Brasilica, v.18, n.3, p.659-669, 2004.

NELSON, R. Modeling forest canopy heights: the effects of canopy shape. Remote Sensing and Environment, v.60, p.327-334, 1997.

NICOTRA, A.B.; CHAZDON, R.L.; IRIARTE, S.V.B. Spatial heterogeneity of light and woody seedling regeneration in tropical wet forests. Ecology, v.80, p.1908-1926, 1999.
PAULA, A.S.; LEMOS FILHO, J.P. Dinâmica do dossel de uma floresta semidecídua no perímetro urbano de Belo Horizonte, MG. Revista Brasileira de Botânica, v.24, n.4, 2001.

PENNINGTON, R. T.; PRADO, D. E.; PENDRY, C. A. Neotropical seasonally dry forests and Quaternary vegetation changes. Journal of Biogeography, v.27, p.261-273, 2000.

RIBEIRO, J.F.; WALTER, B.M.T. Fitofisionomias do bioma Cerrado. In: SANO, S. M.; ALMEIDA, S. P. (Ed.) Cerrado: ambiente e flora. Planaltina: Embrapa - CPAC, 1998. p.89-166.

SAS INSTITUTE. SAS version 8. Cary: 1999-2001.

SILBERNAGEL, J.; MOEUR, M. Modeling canopy openness and understory gap patterns based on image and mapped tree data. Forest Ecology and

Management, v.149, p.217-233, 2001.

SILVA, L. A.; SCARIOT, A. Composição florística e estrutura da comunidade arbórea em uma floresta estacional decidual em afloramento calcário (Fazenda São José, São Domingos, GO, bacia do rio Paranã). Acta Botânica Brasílica, v.17, n.2, p.305-313, 2003.

SILVA, L. A.; SCARIOT, A. Comunidade arbórea de uma floresta estacional decídua sobre afloramento calcário na Bacia do rio Paranã. Revista Árvore, v.28, n.1, p.61-67, 2004a.

SILVA, L. A.; SCARIOT, A. Composição e estrutura da comunidade arbórea de uma floresta estacional decidual sobre afloramento calcário no Brasil central. Revista Árvore, v.28, n.1, p.69-75. 2004b.

TER STEEGE, H. Winphot 5: a programme to analyze vegetation indices, light and light quality from hemispherical photographs. Georgetown: Tropenbos Guyana programme. 1997. (Tropenbos Guyana reports 95-2).

TRICHON, V.; WALTER, J. M. N.; LAUMONIER, Y. Identifying spatial patterns in the tropical rain forest structure using hemispherical photographs. Plant Ecology, v.137, p.227-224, 1998.

R. Árvore, Viçosa-MG, v.31, n.1, p.167-176, 2007 
WELLES, J.M.; NORMAN, J.M. Instrument of indirect measurement of canopy architecture. Agronomic Journal, v.83, p.818-825, 1991.

WENZEL, M.; HAMPEL, H. Regeneración de las principales especies arbóreas del chaco húmedo argentino. Quebracho, v.6, p.5-18, 1998.
ZAR, J.H. Biostatistical analysis. 4. ed. New Jersey: Prentice Hall, 1996. 663p.

ZIPPERLEN, S.W.; PRESS, M. Photosynthesis in relation to growth and seedling ecology of two dipterocarp rain forest tree species. Journal of Ecology, v.84, p.863-876, 1996. 